\title{
Branding of muslim scuba dress: The case study of Rizka Haristi in Bandung
}

\author{
S.B. Haswati \& S.M. Ridjana \\ Telkom University, Bandung, Indonesia
}

\begin{abstract}
The growing of the fashion industry in Indonesia has driven competitiveness within the creative market, marked by numerous prestigious fashion events held every year. As a Muslim fashion brand established since 2015 in Bandung, Rizka Haristi has had to compete with similar brands to create the market opportunity, especially in West Java. Despite Rizka Haristi success in several fashion shows and its sales even reaching a peak in 2018, fluctuating profit is undeniable. It is assumed that the lack of emotional relationship with its consumer, also the use of single promotion media, has become the primary factor of this fluctuation. Hence, the company requires an advertising solution to increase their brand awareness. By conducting qualitative research using various methods, this paper generated a creative strategy toward a particular target audience: bridesmaid. By offering a special package, the program could help the brand to build a more emotional connection and stabilize the profit in the long run.
\end{abstract}

Keywords: branding, Muslim dress, scuba material, fashion, bridesmaid

\section{INTRODUCTION}

The fashion industry significantly contributes to Indonesia's economic growth, especially from the creative sector. The national exports ranked first at $56 \%$ and Gross Domestic Product (GDP), with the second rank of $18.15 \%$ after culinary (Rusiawan et al. 2017). As an impact, it captures the interest of both fashion workers and fashion enthusiasts in Indonesia. Now the public could attend regular prestigious Muslim fashion events in some big cities: the Muslim Fashion Festival (MUFFEST), Jakarta Modest Fashion Week (JMFW), etc. The industry also consists of fashion shows, fairs, talk shows, and design competitions such as contests for products of Muslim fashion and the business environment. It strongly indicates the massive potential of the Muslim fashion industry, especially in Bandung and DKI Jakarta, to transform Indonesia to be the center of the Muslim fashion world.

The journey of Rizka Haristi (RH) began since September 2015. The purpose of the brand is to accommodate women who encounter the difficulty of getting an elegant but comfortable fit-body Muslim dress with an affordable price. With competition among fellow Muslim fashion brands, RH introduces the benefits of customized Muslim dresses made from scuba with a minimalist and elegant design to look beautiful at all events. Scuba or rubber (stretch) that is an elastic fabric made from the core of a rubber thread at a time in the process of making yarn (Astiti 2016). Generally, scuba material is widely used for sportswear. This material has the nature of thick material but is elastic, not easily tangled and neat pieces of fiber material (Septiana \& Siagian 2019) so it is used as an innovation in the use of Muslim RH dresses.

This innovation has brought $\mathrm{RH}$ to various national Muslim fashion events such as the Indonesia Hijab Festival in Bandung (2018), Jakarta Modest Fashion Week (2018), and Muslim Fashion 
Festival (2018-2019) in Jakarta. At the same time, RH was achieving the highest sales in November 2018 and sold 392 Muslim dresses through offline sales at the fashion bazaar and online events conducted on social media on Instagram. However, the data starting from July 2018-June 2019 shows the sales fluctuate, since RH sales rise only when they take part in fashion shows or bazaars at certain events. Unfortunately, sales may decline again right after shows and fairs, or in short, sales tend to be unstable.

It is expected that RH can attract more attention from women, especially bridesmaids as the target audience, which consisted of female students, career women, even the young housewives aged 22 30 years. A bridesmaid is anyone who is supposed to be the closest person, family member, or best friend of the bride who supports them at the wedding. To look remarkable by standing alongside the bride, the dress used by the bridesmaid makes an essential point in the togetherness and remains in harmony with the beauty of the wedding dress (sam Kim \& Lee 2014). The color selection of a bridesmaid dress can create its impression on a wedding with various models and bridesmaid dresses be made according to their respective characteristics. Due to 400,311 couples who got married in West Java recently (Indonesia 2018), this trend can be seen as a huge market opportunity. Thus, it could support momentum for RH to increase its brand awareness in Bandung.

Brand awareness is one of the stages in knowing the ability of how the target audience recognizes, is interested, remembers, and feels familiar with a brand, while awareness, perceived quality, and loyalty to the brand can influence the target audience's purchasing power for a particular product (Rahman \& Triadi 2019). Promotion is also one of the efforts of the brand to build brand awareness and attachment to the consumer experience of a brand (Moriarty et al. 2008). By using promotional mix (including advertising) to deliver product messages, a brand may reach a broader target audience (Wariki et al. 2015). Advertising itself is a form of communication that contains messages sent through particular media, where advertising becomes effective when consumers react according to the wishes of the ad maker (Moriarty et al. 2008).

In the previous promotion, $\mathrm{RH}$ only used social media content on social media on Instagram as the only media to deliver communication messages, whereas in advertising the media or the means to convey product messages usually use coordination in a mix of media with diverse types such as conventional, digital, or combination of both. The lack of resonance with consumers' belief in product messages also impacted on the lack of personal bonding between the brand and consumers (Moriarty et al. 2008). Therefore, RH must consider how to implement the right strategy to increase its brand awareness: not only persuasive and creative but most important, it effectively works.

\section{RESEARCH METHODS}

This research utilizes aqualitative approach as the data collection and facts are based on the observations of the authors, through questionnaires, interviews, and literature studies on phenomena that occur in the community (Sugiyono 2007). Thus, the data are collected through observations, interviews, questionnaires, and literature review to enrich the impression or insight from human behaviors (Kothari 2004). The method of analysis focuses on three characteristics, one of which is demographic (social character), which is fundamental in choosing and identifying the target audience to design messages and select the media according to the target. It is supported by SWOT (Strengths, Weakness, Opportunities, and Threats) analysis studies to explore knowledge about products promoted to consumers since SWOT is an instrument to find out and identify product problems from the internal factor, namely strengths and weaknesses. In contrast, opportunities and threats will describe the marketing influence of external elements (Moriarty et al. 2008).

Moriarty also stated that the AOI method (Activity, Opinion, and Interest) determines the target audience from personal (psychographic) driving factors, namely lifestyle aspects such as activities, interests, and opinions on a product or phenomenon. At the same time, the design process used AISAS as one of the marketing communications models to analyze consumer behavior and designing appropriate media strategy (Sugiyama \& Andree 2010). 


\section{RESULT AND DISCUSSION}

\subsection{Communication message}

The benefits of RH products are providing color selection consultations, from models to customized sizes so that consumers can look beautiful according to their personalities, while the consumer insight from the bridesmaid phenomenon becomes a very important moment in beautifying the appearance. They want Muslim dresses that show character and self-privilege. So, RH wants to portrait the brand as "Muslim dress that is customized so that it can look beautiful according to the character and personality of yourself on a special day".

With the tagline "Stunningly Beauty, Be You Be True", RH believes women can look beautiful and confident according to their character. By using scuba dress, the ladies would be fascinated as if the dress is made to exude their own persona. The communication strategy is used in providing information on product excellence. To provide the best service, appreciation and surprise to convince the target audience to make a purchase, this design utilized FACET Model of Effects Communication approach in the form of affective responses to the stage of resonance of belief (Moriarty et al. 2008). If the viewer could be triggered and feel the energy from the brand message seen through advertisements, they will continue to look forward and share their experiences so that others can feel the same way (Petrescu 2014).

\subsection{Visualization}

The visual pays attention to details on product quality and cohesiveness along with the bridesmaid themes. It also requires the use of informative and persuasive copywriting with advertising approach models such as Compliment Ads (praise) and Question Ads in the form of the use of questions in the headline so that it attracts the target to be more deeply attached to a message to the visual of the ads (Collins 2014).

In the design of logo making, the primary colors used are purple, gold, and ash by using color mixing which results in a series of colors that are: bright colors (tints), tone colors (tones), and dark colors (shades). These colors may trigger specific responses and harmony with the message (Meilani 2013). The supporting logo reads "Be You, Be True" by serif typefaces to give the impression that emphasizes the character of an elegant woman.

\subsection{Media strategy}

The media mix conveys the messages according to the analysis of the target audience and is designed with the AISAS communication model. Attention (A) is a step to shape the first impression of the

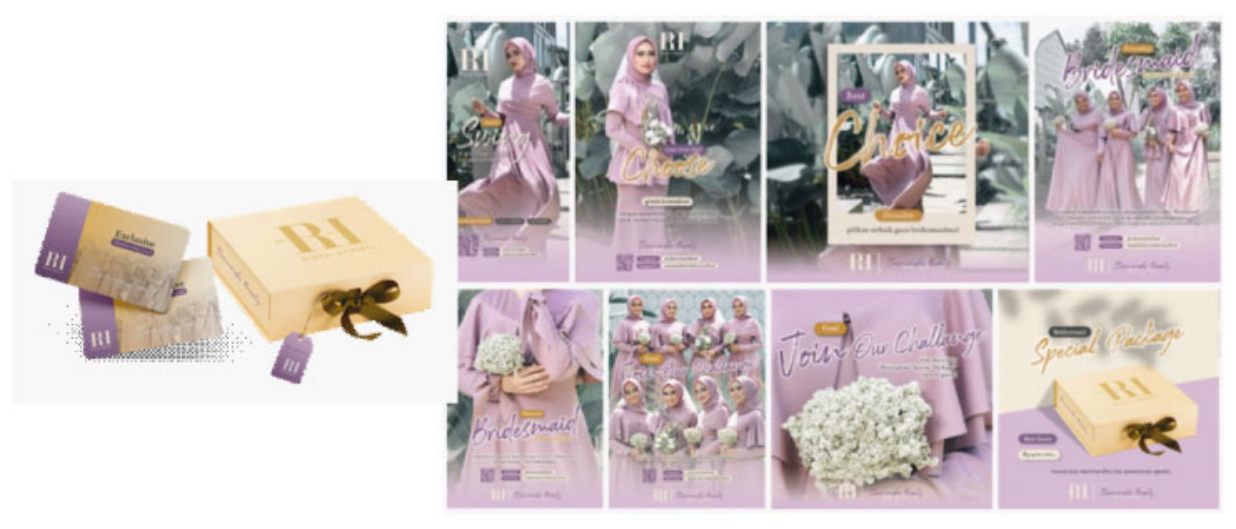

Figure 1. Promotion media of special bridesmaid package RH. (Source: Ridjana 2020) 

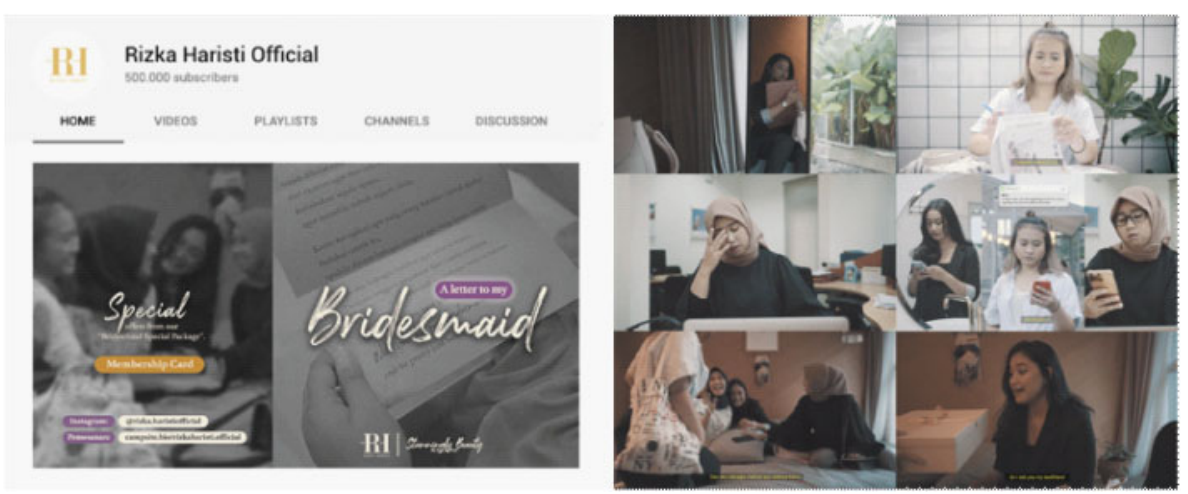

Figure 2. The TVC of bridesmaid special package on YouTube and Instagram. (Source: Ridjana 2020)

RH brand. Thus, the several advertisings are placed on Instagram, flyers are put in beauty salons (MUA or Brides), Muslim salons, and Muslim fashion bazaars based on the target audience's interest in fashion. Also, the poster is set on digital signage in the mall lobby based on the results of an analysis of activities that are often carried out by the target audience.

Interest (I) is the stage to persuade the target audience to know more about the RH brand and to interact and follow information about the brand. By using media that can provide detailed information in the form of visual products with quality graphics, the placement is still similar as in the attention stage. Next, the Search (S) directs the target audience to explore the brand through digital media, which consumers can access by clicking links and scanning barcodes.

When it comes to Action (A) step, the brand will communicate a personal emotional impact on the target audience to tie consumer awareness in recognizing brands, by broadcasting a TVC video placed on YouTube and Instagram TV (IGTV). Finally, Share (S) disseminates RH brand information in the form of word-of-mouth, buzzer, or influencer who were exposed to information by publishing their experiences with brands using social media.

\subsection{Design result}

This design prioritizes "Bridesmaid Special Package" packaging as an innovation to increase the awareness of the target audience in recognizing brands. Packaging can communicate products consistently, effectively in conveying messages and being brand reminders (Moriarty et al. 2008). Not only does this protect the product, but the packaging also provides differentiation between competitors and convincing the target audience to purchase the product (Rahman \& Triadi 2019). The design gift is a membership card as a "surprise" after purchasing a product with special packaging as a strong brand element in creating consumer appeal, where this membership will later provide privileges such as getting discounts, following the activities carried out by the brand in the next promotion, and priority queues in purchases (Kurnia \& Stanley 2013). In this case, the member card is also a benchmark media that has an impact on increasing the number of consumers.

The end of the TVC offers this membership card as a form of reward for purchasing products. The essence of the message is a cohesiveness to "friendship does not mean having to stay together, but it can also be with the nature of mutual understanding with each other". It is similar to the RH brand where one of its advantages is that it provides consultations on the selection of models, colors, and sizes according to the character of the self-visualized. A storytelling video uses the reality of life as a story that can arouse the emotions of the target audience to cause affection for the brand (Collins 2014).

Since meaningful advertising tends to be more effective in the long term (Haswati 2018), the target audience will get certain prizes after purchasing a "Bridesmaid Special Package" product and sharing experiences with the RH brand. The purpose of using merchandise in visual design 
is as a reminder of Rizka Haristi, giving affection and personal confidence to the target audience, and disseminating information about the brand.

\section{CONCLUSION}

The tight competitiveness among market players - especially in Muslim fashion, provoke RH Muslim dress to raise its brand awareness that contains information on excellence and product quality. RH perceives itself as a Muslim fashion brand providing customized Muslim dresses with consultation on the selection of colors and models to look beautiful following one's personality at special moments. In communicating the message, this paper analyzed the target audience's behavior indepth then design creative strategies and sustainable media strategies in order to increase brand awareness. Altogether, the branding activity such as creative strategies and media would impact growing consumers, especially bridesmaids as the primary target audience.

In designing the creative strategy, it is highly recommended for RH to present "Bridesmaid Special Package" as special offers in the form of membership cards that provide an emotional impact in the form of a target audience's confidence in the brand. The communication model of affection and resonance, media strategies based on AOI, and SWOT strategies are expected to have an impact on increasing the number of RH consumers to maintain sales stability in the long run.

\section{REFERENCES}

Astiti, N. D. 2016. Penerapan Material Scuba Terhadap Material Rib Sebagai Aplikasi Eksplorasi Teknik Tekstil Pada Busana Ready to Wear. Skripsi. Telkom University.

Collins, T. 2014. 100 Ways to Create a Great Ad, Laurence King Publishing.

Haswati, S. 2018. Sell and Tell: A Story of Dairy \& Cocoa Print Advertising During Indonesian Colonial Period. 5th Bandung Creative Movement International Conference on Creative Industries 2018 (5th BCM 2018), 2019. Atlantis Press.

Indonesia, B.-S. 2018. Statistical Yearbook of Indonesia 2018. BPS Central Jakarta, Indonesia.

Kothari, C. R. 2004. Research Methodology: Methods and Techniques, New Age International.

Kurnia, P. R. and Stanley, J. R. 2013. Pengaruh Customer Satisfaction Dan Membership Card Loyalty Terhadap Store Loyalty Pada Industri Ritel Kategori Minimarket Di Jakarta. Journal Of Management and Business Review, 10(1):16-28.

Meilani, M. 2013. Teori Warna: Penerapan Lingkaran Warna Dalam Berbusana. Humaniora, 4:326-338.

Moriarty, S., Mitchell, N., and Wells, W. 2008. Advertising Ed.8, Kencana.

Petrescu, M. 2014. Viral Marketing and Social Networks, Business Expert Press.

Rahman, Y. and Triadi, A. 2019. Perancangan Cerita Webtoon Mengenai Budaya Palang Pintu. Desain Komunikasi Visual, Manajemen Desain dan Periklanan (Demandia), 4:15-15.

Rusiawan et al., W. 2017. Data Statistik Dan Hasil Survey. Jakarta: Badan Ekonomi Kreatif. Badan Pusat Statistik.

sam Kim, Y. and Lee, J.-a. 2014. Fashion Styles and Aesthetic Values Represented in Bridesmaid Dresses. 한국의균산업하화지 pISSN, 16, 2014.

Septiana, M. G. and Siagian, M. C. A. 2019. Penerapan Motif Kain Ulos Tumtuman Pada Busana Ready to Wear Deluxe. eProceedings of Art \& Design, 6.

Sugiyama, K. and Andree, T. 2010. The Dentsu Way: Secrets of Cross Switch Marketing from the World's Most Innovative Advertising Agency, McGraw Hill Professional.

Sugiyono, S. 2007. Metode Penelitian Kualitatif Kuantitatif Dan R \& D. Bandung Alf.

Wariki, G. M., Mananeke, L., and Tawas, H. 2015. Pengaruh Bauran Promosi, Persepsi Harga Dan Lokasi Terhadap Keputusan Pembelian Dan Kepuasan Konsumen Pada Perumahan Tamansari Metropolitan Manado. Jurnal EMBA: Jurnal Riset Ekonomi, Manajemen, Bisnis dan Akuntansi, 3. 